China Perspectives

45 | january-february 2003

Varia

\title{
The New Middle Class in Peking: A Case Study
}

Li Jian et Niu Xiaohan

\section{OpenEdition}

Journals

Édition électronique

URL : http://journals.openedition.org/chinaperspectives/228

DOI : 10.4000/chinaperspectives.228

ISSN : 1996-4617

\section{Éditeur}

Centre d'étude français sur la Chine contemporaine

Édition imprimée

Date de publication : 1 février 2003

ISSN : 2070-3449

Référence électronique

Li Jian et Niu Xiaohan, « The New Middle Class in Peking: A Case Study », China Perspectives [En ligne], 45 | january-february 2003, mis en ligne le 23 novembre 2006, consulté le 28 octobre 2019. URL :

http://journals.openedition.org/chinaperspectives/228; DOI : 10.4000/chinaperspectives.228

Ce document a été généré automatiquement le 28 octobre 2019

(c) All rights reserved 


\title{
The New Middle Class in Peking: A Case Study
}

\author{
Li Jian et Niu Xiaohan
}

1 The economic reforms of China since the 1980s have resulted in an increase of national wealth, changed the social and economic structure and created a social group that many observers call China's "new rich" this group as a "new middle class". However, the new rich and the new middle class are different social and economic groups in China. This article looks at the second of these, the new middle class, in Peking.

2 Our research shows that in the current period, there is indeed a new middle class in Peking. The generally accepted view in China is that the middle class has arisen from among the "new white-collar workers" in joint-venture and foreign-owned enterprises, the owners-operators of small and medium-sized private enterprises and individual entrepreneurs ${ }^{3}$. In this article, we call these people the middle class "outside the system" (tizhiwai zhongchan jieji). Here "outside the system" means they work in the non-state-owned sector and do not have the fringe benefits provided by the state.

3 However in addition to the middle class "outside the system", we have found through our research that there is a middle class "within the system" (tizhinei zhongchan jieji). They form the most influential group and the most stable elements of the new middle class in Peking. They work in state-owned work units and enjoy various fringe benefits provided by the state, such as cheap housing, virtually free health care and a pension plan. Through the housing reforms of recent years, many employees in the state-owned sectors became property owners. Overnight, they joined the ranks of the middle class. Without the state-controlled system, they would not have their socio-economic status and private assets. This group survives or falls within the system. For this reason, they are the strongest supporters of the Chinese Communist Party and its current political and economic system.

Object and methodology of study

4 The earliest signs of the new middle class in China emerged in the big cities in the 1980s. Over the last twenty years, the economic reforms have not only created 
diversified forms of ownership and changed China's industrial structure, they have also widened economic and income differences between urban and rural areas and between different regions and cities ${ }^{4}$. The economic level, industrial structure, development of diversified ownership and household income in Peking are different from those in other cities. These factors affect the composition of Peking's new middle class.

However, the most distinctive feature of Peking, which has decisively affected the formation of Peking's new middle class, is its peculiar position as China's political and administrative centre. The new middle class "within the system" in Peking reflects the basic characteristics of China's politics, economics and administration. They play a crucial role in the Party and government policy-making. These people either work in Party or government departments or have very close relations with these departments. They are currently using, and will increasingly use, their political power to protect their newly gained socio-economic status and the system that they rely on for their economic well-being. Studying the new middle class in Peking, both within and outside the system, can provide an important insight into understanding China's present condition and predicting the country's political, economic and social development in the future. In this sense, we can say that a thorough understanding of Peking's middle class "within the system" is a key to understanding the country's political and economic system in the current period.

In Peking many members of the middle class "outside the system" gained their socioeconomic status not only because they had entrepreneurial ability and professional skills, but also because they could, to a great extent, access bureaucratic power and have special relations with the system. The government system generates a range of rights and benefits. These rights and benefits help the recipients to establish an extensive and often extremely profitable social network (guanxi wang). They are the particular social capital, or "organisational capital", that Peking's new middle class both within and outside the system possess and use. The study of Peking's new middle class will reveal the actual function of social capital in a country that is still under the control of the Communist Party.

7 This study is based on in-depth interviews conducted primarily between February and October 2000. Initially, we planned to use a questionnaire survey in order to be able to process large amounts of information. However, soon after we began the survey, we discovered that some questions, such as real household annual income, percentages of non-wage income in total income and how much tax to pay, were too "sensitive" for the respondents to answer. Therefore, we realised that we could not get reliable information and data and decided to abandon the survey and conduct in-depth interviews instead.

8 Before conducting interviews, we carefully determined who and how many people "within the system" and "outside the system" would be interviewed. We first interviewed a respondent to whom we knew his or her economic situation and income very well and took information that he or she told us as reference. Then we interviewed other people who work in the same sector or even in the same work unit. The references had turned out to be a very useful measure to test the information other respondents provided. In this way we not only interviewed a fairly adequate number of respondents, but also got more reliable and accurate information.

9 In total we interviewed 65 people in Peking, which resulted in some eighty hours of recorded tapes and videocassettes. The film shows face-to-face interviews, the living 
conditions of the middle class including their housing with its interior design, the working conditions, and other daily activities.

During the interviews, we found that the housing reforms of recent years provided us with an important measure to identify who are the new middle class in Peking. In this research, we will examine how the housing reforms enable employees "within the system" to become property owners and have enabled them to join the rank of the new middle class.

Understanding the middle class

11 In the West, the concept of the middle class can be traced back to Aristotle. But theories of social class were fully elaborated in the nineteenth century. The most systematic theoretical framework for class is found in the Marxist and Weberian traditions. Within the Marxist tradition of class analysis, class divisions are defined primarily in terms of the link between property relations and exploitation. In a capitalist society, the form of exploitation exercised is based on property rights in relation to the means of production. These property rights generate three basic classes: the capitalist class, which owns the means of production and hires workers; the working class, which does not own the means of production and sells its labour to the capitalists; and the petty bourgeoisie-the middle class, which owns and uses the means of production without hiring others ${ }^{6}$.

12 Although many scholars have been working to find contrasts between Marx and Weber ${ }^{7}$, at least one thing is common to their conclusions: classes are economically determined. The control over economic resources is also central to the Weberian class analysis. In Economy and Society, Weber wrote, the class situation means the typical productivity of: 1. procuring goods; 2. gaining a position in life; and 3. finding inner satisfaction, a probability which derives from the relative control over goods and skills and from their income-producing uses within a given economic order. ${ }^{8}$ Weber's class definition lends to it a certain continuity with Marx's stress on property relations. Marx saw the middle class as auxiliary to the capitalist class. ${ }^{9}$ For Weber, the middle class came into being with the growing bureaucratisation of modern society and rationalisation of capitalist production ${ }^{10}$. While Marx focuses on the control of the means of production, Weber also insists on considering the different control over the methods of production in terms of "skill".

13 In the 1950s, C Write Mills raised a concept of the new middle class in his book White Collar ${ }^{11}$. The new middle class is different from the independent and entrepreneurial old middle class. They include the middle managers and bureaucrats, the technocrats, professionals and service workers. They are basically salaried, conformist and entrepreneurial people. Since the emergence of the new middle class, the old middle class-the small business class-has not disappeared, but they have declined in relative numbers and influence.

14 In developed countries, such as the United States, most people think of themselves as middle class, whether shop assistants, cleaners, accountants or doctors. As long as they work for a living and do not depend on either social welfare or inherited wealth, they are likely to think of themselves as middle class. Although there are different definitions of middle class, there is a general understanding of what constitutes the middle class in the West. The middle class may include the middle and upper levels of clerical workers, people in technical and professional occupations, supervisors, businessmen and farmers. 

the features of the Chinese middle class; and who belongs to it? Many people, including scholars in China recognise the existence of the new rich created by the reforms. Researchers have carried out major studies of the disparity between the incomes of the urban rich and the urban poor ${ }^{12}$. However, Chinese scholars generally feel that there was no middle class in China in the 1990s. Li Peilin argues that only when white-collar workers account for $40 \%$ of the population [labour force], can there be a middle class in a society. According to this theory, as a majority of China's labour force being still in the agricultural sector, and transferring them to the non-agricultural sector remaining a major task, there is no middle class in China ${ }^{13}$.

Li Qiang has studied the changes in the so-called social "intermediate stratum"(zhongchan jieceng) after the founding of the People's Republic of China. He argues that from the early 1950s to the early 1980s, the "intermediate stratum" in Chinese society was mainly composed of ordinary officials, ordinary intellectuals and workers in the state-owned enterprises. After the reforms of the 1980s and 1990s, this group lost their socio-economic status. According to him, in the 1990s, a new "intermediate stratum" emerged. These were young people in their 20s and 30s with a good education. They worked in joint ventures, foreign-owned enterprises, and in the newly emerging industrial sectors. This group came about as a result of changes in social and industrial structures. Although the group is still very small today, it is taking the place of the old "intermediate stratum" ${ }^{14}$.

Li Qiang does not use the concept of middle class to identify these young people in the social "intermediate stratum". Instead he calls them an interest group (liyi qunti). According to him, class means that "integration of interest" (liyi zuhe) has been completed and the people in a class have relatively stable and similar material interests. Today, the interest structure (liyi jiegou) of Chinese society is changing rapidly. Various social interest groups are in the process of disorganisation and reintegration. Therefore, according to Li, class or social status are not appropriate concepts for describing the reality of China's social landscape. In addition, he argues, before the economic reforms the concept of class had long been used indiscriminately within society. Chinese people had become tired of hearing about class and class analysis ${ }^{15}$.

18 In contrast with the academic view, a number of Chinese journalists have in recent years acknowledged the emergence of an urban middle class. They consider that the annual household income of the Chinese middle class ranges from US\$10,000 US $\$ 50,000$ [83,000 - 415,000 yuan]. They are in the middle level of the society and political power structure and consist of non-manual labourers. They are white-collar workers. Because of their high incomes, they can copy and follow the lifestyle of the middle class in Western countries, especially their culture of consumption. ${ }^{16}$ These journalists firmly exclude Party and government officials from the Chinese middle class. According to them, though these officials may live in spacious apartments, they cannot have a middle class lifestyle and are struggling to earn enough to feed and clothe themselves ${ }^{17}$.

19 Among Western scholars, David S. G. Goodman has used the concept of the "new middle class" to describe the people who have power and wealth in China today. In particular he studied the new middle class in Shanxi province in the north-west. He divided them into three major categories: owner-operators; managers, including state capitalists, 
social capitalists and suburban executives; and service providers, including financial managers, business administrators, and lawyers. According to him, in 1997 a monthly income of 5,000 to 6,000 yuan was regarded as "well-off" in the more developed coastal areas of southern and eastern China. In the inland regions, 3,500 - 4,500 yuan could allow people a comfortable lifestyle ${ }^{18}$.

During our interviews we asked respondents if they felt there was a middle class in Peking and who belonged to this class. The responses varied. Some respondents regarded themselves without any doubt as belonging to a middle class. Others denied they belonged to the middle class, although their occupations and incomes fitted this distinction. Some respondents identified the middle class from a cultural perspective and system of values while others considered occupation and educational level important standards for middle class status. The majority of respondents however regarded household income as the most decisive factor.

21 A government research official told us of an allegory commonly heard in the late 1980s and the early 1990s. It described ten groups of people in Chinese society ${ }^{19}$. Among them, the six and seventh groups were professionals, such as doctors, lawyers and actors, who could be regarded as the middle class. The eighth and ninth groups of people, teachers, researchers, and officials in less powerful Party and government departments, might be identified as a lower-middle class.

He added: "Between 1996-1998, many employees in state-owned enterprises were laid off, but new industrial sectors such as information technology were emerging in Peking. Employees in these newly emerging sectors are the middle class. Many of them graduated from good universities and earn 100,000 yuan a year. In addition, whitecollar workers in joint venture and foreign enterprises and employees in some stateowned industrial monopolies also belong to the middle class" ${ }^{20}$.

23 A journalist with 18 years experience in reporting on enterprises and the economy told us: "Today, to own an apartment and have a car are the symbols of the middle class. But the middle class in China and the middle class in Western countries are very different. We often find many members of China's middle class are less educated and have little sense of law. In a Western society, the middle class is the force behind social stability. But in China they are actually social "rebels". The Chinese middle class is the cause of social instability. I think a true middle class should be representative of the mainstream system of values and the force of social stability. Household income cannot be the only standard for identifying the middle class" ${ }^{21}$.

An owner of a small private company that sells building materials told us: "In the last two years, my company's annual net profit was more than 200,000 yuan. But I don't dare to buy an apartment in Peking now. At present my urgent need is to buy a car. I cannot always take a taxi to go to meet my customers. If I buy a moderately sized car that can be used for my business, I will have to spend one year's profit. My wife and daughter are still living in Guangdong. Although they don't need me to send them money, I must save money for our daughter's university education later, for unexpected health problems and for our retirement. You can say I am the middle class but I cannot be easy-going. In my opinion, the only standard for identifying class is money. In other words, how much money you have"22.

25 A senior manager in a private enterprise told us: "My household's annual income was about 180,000 yuan in 1999. I think my family belongs to the middle class in Peking. But income is not the only standard for being a member of the middle class. A very 
important feature of the middle class is that they set high requirements for the quality of life they want. Now I am mostly concerned about how to improve the quality of life for my family" ${ }^{23}$.

A journalist in the Peking Television Station told us: "My annual income was 60,000 yuan and my husband earned 26,000 yuan in 1999. Compared to my colleagues, my income belongs to the upper-middle level. A few years ago, I came to Peking from another province and worked in several media-related work units. We don't have an apartment assigned by the work unit and have to rent a private apartment. Since we began working in Peking we have been under financial pressure. My family is certainly not middle class" ${ }^{24}$.

Table 1 Market and System Housing Prices and Their Differences (Yuan)

\begin{tabular}{|c|c|c|c|}
\hline Housing location & $\begin{array}{c}\text { Market } \\
\text { housing prices }\end{array}$ & $\begin{array}{c}\text { System housing } \\
\text { prices }\end{array}$ & $\begin{array}{l}\text { Difference in } \\
\text { market housing } \\
\text { and system } \\
\text { housing prices }\end{array}$ \\
\hline Inner city & $8,000-10,000^{*}$ & 1,480 & 7,520 \\
\hline $\begin{array}{l}\text { Between second } \\
\text { and third ring road }\end{array}$ & $7,000-8,000^{44}$ & 1,480 & 6,020 \\
\hline $\begin{array}{l}\text { Between third and } \\
\text { fourth ring road }\end{array}$ & $5,000-6,000^{* * *}$ & 1,480 & 4,020 \\
\hline Average & 7,300 & 1,480 & 5,850 \\
\hline
\end{tabular}

A young pre-sales service manager in a private computer software company told us: "I can earn more than 10,000 yuan a month, which includes my wages, bonus and business travelling allowance. Compared to the people in my age group and with a similar educational level [three-year college graduate], I can be considered middle class. But in China, the people who really have money and also don't need to work hard to make money are the officials. I used to work in a large Chinese insurance company. All division chief level officials' housing in that company is worth one million yuan and above. With my income I could never think of buying an apartment like theirs. One's occupation is the most important criterion to decide class" 25 .

To summarise, Chinese scholars generally deny there was a middle class in China in 1990s. Some scholars argue that the white-collar workers only made up a small percentage of the labour force. So China is far from being a middle-class society. Others acknowledge there has been an "intermediate stratum" since the 1950s. In the 1980 s and the 1990s, a new intermediate stratum, which is mainly composed of young educated people, emerged. These young people are working in joint ventures, foreign enterprises and in some newly emerging industrial sectors. However, they don't identify these people as middle-class.

Some young journalists and most of our respondents have acknowledged the emergence of a middle class in recent years. They regarded a family's economic situation and income as the basic standards for identifying middle class status. According to them, the household income of the Peking middle class was 80,000 yuan and above in 2000. The symbols of the middle class are to have an apartment and a car. The Peking middle class consists of the new white-collar workers, employees in state 
industrial monopolies, and some professionals and private entrepreneurs. However journalists writing on this subject exclude Party and government officials from the Chinese middle class.

In our research we used the economic yardstick to identify a middle class. We found that there is indeed a middle class in China. In contrast to journalists' conclusion that the Party and government officials are not the middle class, we discovered that many members of the new middle class are those who work in the Party and government organisations. They are today the most stable elements of the new middle class in Peking. Thanks to the recent housing reforms, the system helped them become owners of property and enabled them to become the middle class.

Household income, housing reforms and the middle class in Peking

Level of household income is an important factor in identifying the middle classes. It is well-known that the true incomes of Peking households are very different from official statistics. Even the figures from government research institutes and the Bureau of Statistics on China's urban income differ ${ }^{26}$. Many studies have been done on urban household income, but the figures in these studies remain inaccurate. Urban household income in China includes many items, such as wages, bonuses and various subsidieshousing, transportation, telecommunications, children's education, free travel, and even subsidised lunches. Who can access these subsidies and how much an employee gains depends on the economic situation and administrative influence of his or her work unit. In recent years the income gained by some urban households from their assets has been rapidly increasing ${ }^{27}$. They include stock dividends, bank interest, bond yields and housing rents. In addition, many urban residents have second and third jobs earning a so-called "grey income (huise shouru)". Some people also have a "black income (heise shouru)", which comes from illegal economic activities. None of these incomes are transparent and can therefore not be easily calculated.

Being the owner of an apartment is an alternative way to define China's middle class today. China's housing reforms in the last two years provide us with an objective measure to study Peking household incomes and the new middle class. At the end of 1998, the Peking municipal government abolished the system of the administrative allotment of public housing (welfare housing) and implemented the system of commercialising housing allotments. This system involves replacing the government assignment of housing with an increase in employee incomes, establishing housing accumulation funds and encouraging employees in state-owned work units to buy commercial housing on the market ${ }^{28}$. 
Table 2 The Difference Between System Housing Prices and Market Housing Prices (1,000 yuan)

\begin{tabular}{|c|c|c|c|c|c|}
\hline Housing prices & $\begin{array}{l}\text { System } \\
\text { housing } \\
\text { price }\end{array}$ & $\begin{array}{l}\text { Market } \\
\text { housing price } \\
\text { 10,000 ywan } \\
\text { per square } \\
\text { metre }\end{array}$ & $\begin{array}{l}\text { Market: } \\
\text { housing price } \\
\text { T,000 yuan } \\
\text { per squars } \\
\text { metre }\end{array}$ & $\begin{array}{l}\text { Market } \\
\text { housing price } \\
5,000 \text { youn } \\
\text { per square } \\
\text { metre. }\end{array}$ & $\begin{array}{c}\text { Average } \\
\text { market } \\
\text { housing } \\
\text { price }\end{array}$ \\
\hline $\begin{array}{l}\text { Pay off in one } \\
\text { lump-sum }\end{array}$ & 148.0 & $1,000.0$ & 700.0 & 5000 & 733.3 \\
\hline $\begin{array}{l}\text { Over-payment } \\
\text { without mortgage }\end{array}$ & & 852.0 & 552.0 & 3320 & 578.7 \\
\hline Downpayment & 44.4 & 300.0 & 210.0 & 150.0 & 220.0 \\
\hline $\begin{array}{l}\text { Different amount } \\
\text { of mortgages }\end{array}$ & 103.6 & 700.0 & 490.0 & 3500 & 513.3 \\
\hline $\begin{array}{l}\text { Total principal and } \\
\text { Interest }\end{array}$ & 153.2 & $1,034.9$ & 724.4 & $517 . A$ & 758.9 \\
\hline $\begin{array}{l}\text { Annual amount of } \\
\text { mortgages }\end{array}$ & 10.2 & 69.0 & 48.3 & 34.5 & 50.6 \\
\hline $\begin{array}{l}\text { Total prices after } \\
\text { paying off } \\
\text { mortigages }\end{array}$ & 197.6 & $1,334.9$ & 934.4 & 667.4 & 978.9 \\
\hline $\begin{array}{l}\text { Over-payment with } \\
\text { mortgages }\end{array}$ & & $1,137.3$ & 736.8 & 469.8 & 781.3 \\
\hline $\begin{array}{l}\text { Annual over- } \\
\text { payment /year }\end{array}$ & & 75.8 & 49.1 & 31.3 & 521 \\
\hline
\end{tabular}

In 1998 the State Council set the regulations on living area for officials at every rank in the Party and government and for the same ranking personnel in state-owned work units $^{29}$. According to this document, entitled No. 23, the living area for officials at bureau level (juji) and same ranking personnel is 120 square metres, 105 square metres for vice bureau level (fujuji) officials and same ranking personnel, 90 square metres and 80 square metres for division level (chuji) and vice division level (fuchuji) officials and same ranking personnel, 70 square metres for section level (keji) officials and same ranking personnel, and 60 square metres for ordinary employees who have worked for 25 years or more. According to these regulations, the money that an employee "within the system" (tizhinei guyuan) spends on buying housing should be four times the local average annual wage divided by sixty.

However, the real price of housing bought by employees within the system is very different from that stipulated by the regulations. The calculation of housing prices and the procedures for purchasing housing are very complicated. Some employees within the system paid considerably less than the standard price. Prices paid depend on many factors, such as the number of years in employment, an employee's rank and the financial situation of his or her work unit. Some employees with the same official ranking but in different work units paid quite different prices when purchasing apartments of the same quality and in the same location. Even employees in the same work unit and of the same rank paid different prices for the same-sized apartments in the same building. A manager in a large state-owned trading company told us: "In this building [which was bought by his company and resold to the employees in the company], every family bought their apartments at different prices although some apartments are the same size, on the same floor, facing the same direction"30.

In our research we found that housing prices for employees within the system in Peking are generally 1,480 yuan per square metre (in this article we call this price "the system housing price" in order to distinguish it from the market housing price). This price is set by the Peking municipal government and is not available to employees 
"outside the system". Because of different areas and the different quality of housing, the prices of housing in Peking vary greatly. But for employees within the system, no matter where the apartment buildings are located or the quality of the buildings, they generally only pay 1,480 yuan per square metre. Most residential buildings of Party and government departments, the state-owned companies, banks and institutions in Peking are within the fourth ring road or in the areas where housing prices have a great tendency to increase, such as the Zhongguancun area, popularly known as China's Silicon Valley.

According to our investigation, in October 2000 market housing prices could be divided into three groups within the fourth ring road. The price of housing in the inner city (within the second ring road) ranged from 8,000 to 10,000 yuan and above per square metre. The price of housing between the second ring and third ring roads was from 7,000 to 8,000 yuan per square metre. The price of housing between the third ring and fourth ring roads was between 5,000 to 6,000 yuan per square metre. An article in the newspaper Jingpin gouwu zhinan (Shopping Guide), gives a detailed report on the commercial housing price in Peking. The average commercial housing prices within the fourth ring road is 5,000 yuan and above per square metre ${ }^{31}$. These figures clearly show the big difference between "the system housing price" (1,480 yuan) and the market housing prices (from 5,000 yuan to 10,000 yuan and above) - see Table 1 .

After implementing the housing reform programme, the Peking housing market boomed. Many buyers of commercial housing were from Party and government departments and state-owned enterprises. In Chinese, this is called "group purchasing (jituan goumai)". Zhongguo jianzhu bao (China Construction Daily) reported: "Some wealthy and powerful Party and government organisations, state institutions and enterprises use every means, using co-operative construction with employees as an excuse, to raise large sums of money to buy new housing at market prices. Then they resell these apartments to their employees at much cheaper prices"32. Group purchasing is the reason for the increase of housing prices in Peking.

In the purchase of housing, employees within the system only pay a small part of the money and their work units pay the rest. After these employees buy apartments from their work units, they not only have the right to live in the apartments, more importantly, they have property rights and become the owners of those apartments. Their right to use and own the apartments are acknowledged and protected by law. The huge amount paid by the work units to buy housing can be regarded as part of the employees' income and those apartments become the employees' personal assets. Through housing purchases, these employees within the system complete the transition from the proletariat to the new middle class overnight. In the case studies to follow, we will show how the housing reforms have effectively created a propertied class in Peking.

Compared to employees within the system, employees outside the system have to pay the full market price for purchasing housing. Here the difference between "the system housing price" and market housing prices can be regarded as expenditure of employees outside the system and income of employees within the system. People generally think that some individual workers, owners of private enterprises, and employees in jointventure and foreign-owned enterprises are the winners of the reforms and the new middle class in Peking. However, our research finds that many members of the socalled new middle class cannot even afford to buy an apartment or at least cannot 
afford to buy a similar apartment, in terms of location and housing quality, that employees within the system are able to buy.

Here we can make a simple calculation of the income of employees within the system from their purchase of cheap housing. In order to understand their real income, we need not only calculate the current and absolute price difference between the system housing price and market housing prices, we also need to calculate the price difference after paying off a mortgage. The purchase of housing is a huge expense for most buyers, especially for employees outside the system. Now almost all of them buy their housing with mortgages. ${ }^{33}$

We take a 100-square-metre apartment at prices ranging from 10,000 yuan, 7,000 yuan, and 5,000 yuan per square metre as examples and compare the differences between system housing price and market housing prices. (See Table 2)

For buying a 100-square-metre apartment priced at 10,000 yuan, 7,000 yuan, or 5,000 yuan per square metre in one lump-sum payment, employees within the system will pay the same housing price-148,000 yuan. Employees outside the system will pay $1,000,000$ yuan, 700,000 yuan and 500,000 yuan for buying them. Differences between the two system housing prices are 852,000 yuan, 552,000 yuan, and 352,000 yuan. The average difference is 585,000 yuan. That means that an employee outside the system has to pay an average of 585,000 yuan more than an employee within the system pays to buy a 100-square-metre apartment. For an employee within the system, this 585,000 yuan can be regarded as part of his income.

43 In reality, many employees within the system did not borrow money to buy housing due to low system housing prices. But many employees outside the system have to borrow money from financial institutions. To simplify the calculation, we suppose that all housing buyers, both employees within the system and outside the system, pay $30 \%$ downpayment and $70 \%$ with a 15 -year mortgage.

To buy a 100-square-metre apartment, an employee within the system will pay 44,400 yuan $(148,000 \div 0.3)$ downpayment and borrow 103,600 yuan. By the current mortgage interest of 5.58\% (December 2000), interest paid on a 15-year mortgage is 49,562 yuan and principal and interest are 153,162 yuan. The total system housing price of a 100square-metre apartment is 197,600 yuan $(148,000+49,562)$.

If an employee outside the system buys a 100-square-metre apartment at a price of 10,000 yuan per square metre, the downpayment is 300,000 yuan and the mortgage 700,000 yuan. Interest paid on a 15-year mortgage is 334,900 yuan, and principal and interest are 1,034,900 yuan. The total housing price is 1,334,900 yuan. The difference between the housing price systems is $1,137,300$ yuan. This means that an employee within the system can increase his household income by 75,800 yuan a year for the next 15 years $(1,137,300 \div 15)$.

To buy a 100-square-metre apartment at a price of 7,000 yuan per square metre, an employee outside the system will pay 210,000 yuan as downpayment and take out a mortgage of 490,000 yuan. Interest paid on a 15-year mortgage is 234,400 yuan, and principal and interest are 724,400 yuan. The total housing price is 934,400 yuan. The difference between the two systems is 736,800 yuan. In comparison, an employee within the system can increase his household income by 49,100 yuan a year for the next 15 years. 

employee outside the system will pay 150,000 yuan as downpayment and take out a mortgage of 350,000 yuan. Interest paid on a 15-year mortgage is 167,000 yuan and the principal and interest are 517,000 yuan. Actual housing price is 667,000 yuan. The difference between the two systems is 469,400 yuan. The household income of an employee within the system can thus increase by 31,300 yuan a year for the next 15 years. 7,000 yuan, and 5,000 yuan per square metre is 978,767 yuan after paying off a mortgage and the difference between the two systems is 781,167 yuan. If we divide 781,167 yuan by 15 (years), the annual household income of employees "within the system" will increase by 52,078 yuan over the next 15 years.

Case studies

Several of our interviews help give a better understanding of the true income of employees within the system in terms of the following questions. How much did they receive from purchasing housing at system housing prices? And why should they be called the new middle class?

50 In the cases studies, we compared the different prices of two housing systems and calculated the housing income of employees "within the system" in Peking. Although some joint ventures, foreign-funded firms and even a few private enterprises give their employees housing subsidies, the subsidies are so tiny that they still have to take out big mortgages to buy housing at market prices.

51 In contrast to those high-income earners "outside the system", almost all employees within the system bought housing by paying in one lump-sum because of the cheap price of "system housing". These purchases have made these employees within the system a propertied class. If we look at their annual wages, however, they can appear to belong to the lower-income group. In 1998 the average annual wage of workers and staff in Peking was 12,285 yuan. The average wage of workers and staff in the stateowned sector was 11,971 yuan $^{34}$. A 100-square-metre apartment at the market housing price of 5,000 yuan, 7,000 yuan and 10,000 yuan a square metre is, respectively, worth 41 years, 58 years and 83 years of the wages of an employee within the system. The prices of an apartment after paying off the mortgages are equivalent respectively to 54 years, 76 years and 108 years of the total wages of the same employees. From their income, it is possible to believe that they would never dream of becoming house owners, but they are. The government system has heavily subsidised their transformation into property owners and has made them the middle class within the system.

52 We also found that some employees within the system already owned two or even more apartments. By renting their spare housing, they can have two to five times more income than their annual wage. Employees "within the system" not only own apartments valued at tens of thousands yuan or even one million yuan and above, they also have relatively stable jobs and income. Their work units provide them free medical treatment and a pension plan. A white-collar worker in a foreign-funded enterprise told us: "Our wages have less value than the wages of officials. We have to spend much more to buy a low quality apartment in a worse area. We have to pay all our medical expenses, but their work units pay $90 \%$ or even $100 \%$ of their medical expenses. We

China Perspectives, 45 | january-february 2003 
have to save money for our retirement. They have the public pensions. One yuan is equivalent to 50 cents for us, but to 5 yuan for them"35.

Table 3 Respondents' Personal Situations

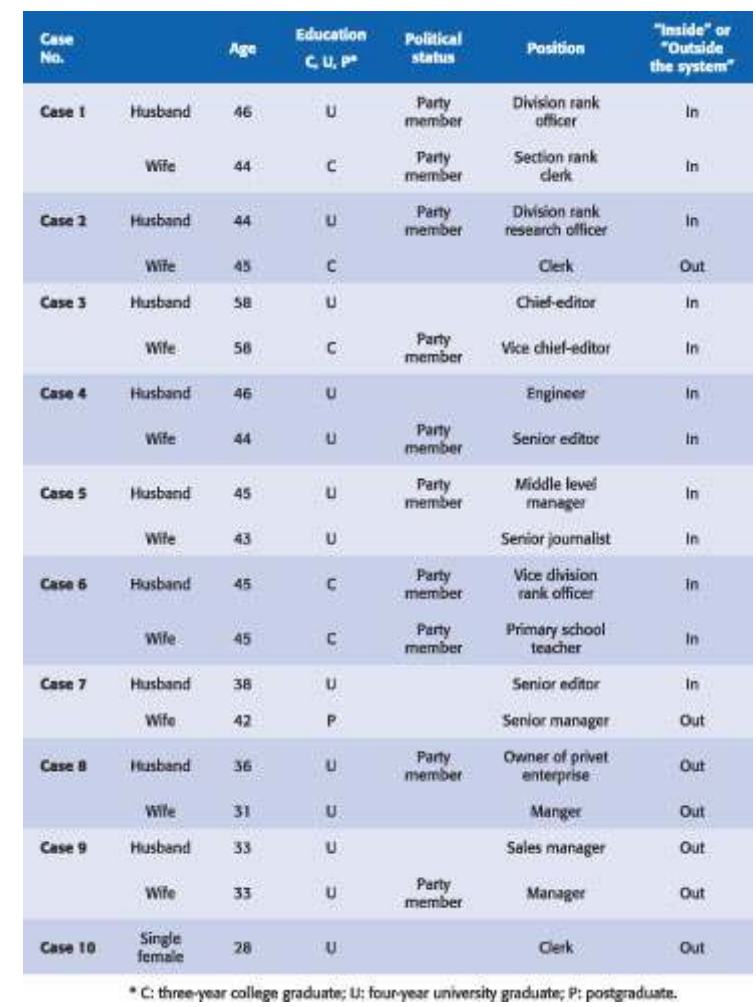

${ }^{*}$ C: three-year? college graduate. U: four-year? university graduate. P: postgraduate.

A lawyer within the system told us: "My annual wage is 48,000 yuan but it is equal to 100,000 yuan for an employee outside the system. This 100-square-metre apartment cost me 100,000 yuan. They have to spend 800,000 yuan to buy it, or 60,000 yuan for one-year's rent. The company gives me the use of a company car and also pays all the expenses for it, worth roughly 30,000 yuan a year. This car has become my own personal asset. The company pays me 10,000 yuan a year for telecommunications costs. Every year, I travel overseas several times because my company has a lot of international business. As you know, these are partly business trips and partly tourism at the public expense. If a private enterprise owner goes overseas for business, he has to travel at his own expense. If we count all of this income, my annual income is at least 100,000 yuan"36.

54 A survey on preferred choice of occupation, conducted by the Chinese Academy of Social Sciences, gives support to our findings in another way. From July to August 1999, researchers from the Chinese Academy of Social Sciences conducted a questionnaire survey on 2,477 people aged 16 and above in 63 cities. The survey shows that although in recent years individual entrepreneurs, owners of private enterprises, employees in foreign and joint-venture enterprises and in entertainment are high profile and are regarded as high earners, occupations within the system are still preferred by most people, with government and Party officials being the first choice of position. Among 50 occupations, the top eight preferred posts are senior official in the Party and government, computer technician (first choice for 16 to 30 year-olds), official in 
industrial, commercial and taxation organisations, private entrepreneur, judge, lawyer, doctor and public procurator ${ }^{37}$. Among the top eight, six can be regarded as occupations "within the system".

In studying China's transition to a market economy, a number of scholars have carried out extensive studies on changes in income and rewards of redistributors (administrators) or producers (entrepreneurs, workers). Victor Nee has argued that the market transition reduced the rewards to former redistributors while the better educated, skilled workers, entrepreneurs and other people who are close to production have made greater gains $\mathrm{s}^{38}$. Huang Yasheng finds that the income gap of government officials and enterprises employees rapidly widened in favour of producers in the $1980 \mathrm{~s}^{39}$.

Some other researchers argue that administrators still hold strong bargaining power. With the lessening of central control, administrators and managers can obtain more benefits for themselves. These rewards were usually not in terms of fixed wages, but in housing and other fringe benefits ${ }^{40}$. Guthrie in his recent study found that producers close to the market and the most subject to intense competition are actually the least rewarded ${ }^{41}$.

The findings of our research show that by the late 1990s, employees "within the system" were generally the biggest winners from the reforms. As holders of political power and policy makers, they have obtained and will obtain more benefits than employees "outside the system" by creating policies and practices that are particularly advantageous for themselves.

THIS study shows that by early 2000 a middle class had emerged in Peking. Generally speaking, members of the middle class are white-collar workers, meaning mainly clerks, technical personal, middle-level mangers in joint ventures and foreign-owned enterprises and professionals in the newly emerging industrial sectors. With the rapid development of new industrial sectors and joint ventures and foreign-owned enterprises after the mid-1990s, the number of white-collar workers has been increasing. The middle class also includes owners of small and medium-sized private enterprises and some individual entrepreneurs. They are the elements of this class whose positions are not stable. The market transition and economic restructuring have had a significant impact on their lives. Some of these small private enterprise owners and individual entrepreneurs could become the new rich in a short time, while others may fall back into their original low-income socio-economic groups. The rapid changes in their economic and social status reflect the speed of the transformation of China's economy and society.

In contrast to the ordinary idea that the middle class is mainly composed of the above group of people, our study finds that a majority of this class in Peking are employees within the system. They are the most stable elements of this class. A basic characteristic of the middle class within the system is that they stick to and strongly support the system. Without the system, they would lose the source of their interests and privileges. They survive or fall with the system. Therefore, they rely on the system and the political situation remaining stable. In our research, we found that even laidoff employees from Party and government sectors are entitled to benefits from the system. For example, in streamlining some Party and government organisations in 1998 , laid-off employees in these departments were allowed to choose to work in profitmaking companies still operating under their former departments and they could still 
live in and later buy their current housing. Some laid-off employees were given the opportunity to attend China's best universities to study useful majors, with their work units paying for their tuition. It is the CCP-controlled system which has created this new middle class. Hence we believe the members of this new middle class "within the system" will use all their means to support the CCP system to protect their new situation.

Table 4 Differences Between System Housing Prices and Market Housing Prices and Household Income ( 1,000 yuan)

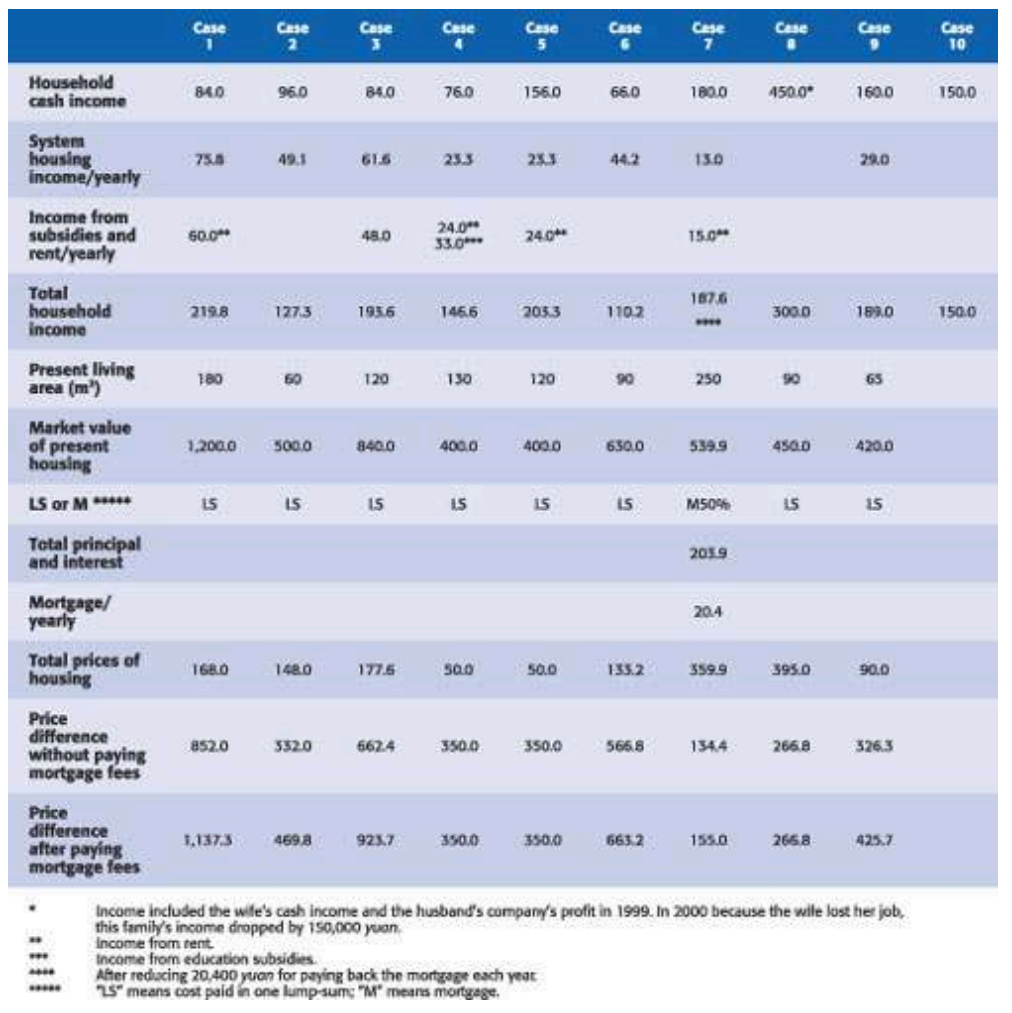

The middle class within the system also have a crucial influence on government policymaking. Through the housing reforms they became property owners in a very short time. Now they are not only Party and government officials and policy-makers, but also property owners and members of the new middle class. Their new socio-economic status will have a great impact on China's political, social and economic development. They are willing to make use of their power to protect existing interests and seek more for themselves. The process of policy-making in the Party and government is that employees at the section level write policy proposals, which they report to division and bureau level officials, and which are finally approved by the relevant government ministry to become formal policy. In recent years many officials at the division and section levels have become part of the new middle class. They have formed common economic interests with the continuance of the current system. Protecting their private assets, the people who have the same economic interests, and the system that they rely on for their livelihoods are likely to become the first and most decisive factor when they make policy. We will examine the influence of the middle class "within the system" on policy-making in future research.

61 This study actually shows that inequalities between employees within the system and employees outside the system have further increased under the housing reforms. Even 
within the system the inequalities between employees in the state-monopolistic industrial sector or those sectors with a better economic performance and employees in other state sectors are also increasing. As society becomes increasingly unequal, this is likely to be the cause of much social and political instability.

This research has been kindly supported by the Centre for East and Southeast Asian Studies of Lund University, Sweden. We would like to thank Mia Turner, David S. G. Goodman, Michael Schoenhals, Anne-Marie Brady and Guo Xiaolin for extensive comments on earlier drafts. We would especially like to thank anonymous respondents for offering us valuable information.

Case No. 1 (Interview No. 20, 2000)

Husband, 46 years old, four-year university graduate (1), Party member and division rank official in a government ministry, with an annual cash income of 24,000 yuan (2). Wife, 44 years old, three-year college graduate, Party member, a section level clerk in a state bank, with an annual cash income of 60,000 yuan. They have a son at junior high school.

They own two apartments. They bought the first apartment within the third ring road for 20,000 yuan. It is worth 200,000 yuan in the Peking housing market. In 1999, they spent a lump-sum payment of 148,000 yuan buying a new 100-square-metre high quality apartment from the ministry that employs the husband. The apartment building is located near the south-eastern second ring road, a central location where many foreign enterprises are based. His work unit bought 120 apartments in this housing area, only for officials of division rank and above, at the market price of 10,000 yuan per square metre, then resold these apartments to their own staff at the system housing price.

The wife told us: "After fitting out the apartment, we are going to rent the new apartment to foreign professionals who will be working in China for extended periods. The rent we will ask is less than that for government-built apartments for foreigners. And our apartment is in better condition. We think that foreigners have a sense of the law and will not damage the apartment. If they can help our son to learn English, we can even lower the rent." She estimates that she will get a rent of 70,000 yuan a year and can save rental income for their son to study overseas later on.

The difference between the two system housing prices for this family is 75,800 yuan per year. Adding "system housing income" into their household income, their annual income becomes 171,800 yuan (without considering the husband's overseas earnings). If they receive 60,000 yuan as rental income, their total annual income will be 219,800 yuan. (See Table 4)

1. In the following cases, all respondents have a college and above educational level. This is because from the mid-1980s only people with college and above educational levels were permitted to work in the Party and government organisations, state-owned institutions and universities. For employees without such an educational level, their work units created various opportunities to help them to obtain a university certificate or a degree.

2. He often works in an overseas office that is run by his ministry. When he works overseas he earns two wages. His income in China is 24,000 yuan.

Case No. 2 (Interview 14, 2000)

67 Husband, 44 years old, four-year university graduate, Party member and division rank officer in a ministry research institute, with an annual cash income of 60,000 yuan (including salary, transportation and telecommunications subsidies). Wife, 45 years old, 
three-year college graduate, working in a private enterprise, with an annual cash income of 36,000 yuan. Their daughter is a senior high school student.

They own a 60-square-metre apartment in the ministry's living quarters, three kilometres away from Peking's Silicon Valley, Zhongguancun. They bought this apartment for 30,000 yuan. Because their current living area does not reach division rank officer entitlement, the husband can buy a new 100-square-metre apartment at "the system housing price". But he has to sell the present apartment to the institute for less than 20,000 yuan. At the time of the interview, his work unit had not yet decided where it would buy the new apartment buildings. But the market price of new apartments in the area that the ministry was considering to buy was at least 5,000 yuan per square metre. We calculate that if his new apartment at a price of 5,000 yuan per square metre, the difference between the market price and the system price is 46,9800 yuan after paying off the mortgage. Their household income for the next 15 years will increase 31,300 yuan each year and the total annual household income will be 127,300 yuan.

Case No. 3 (Interview No. 17, 2000)

Husband, 58 years old, four-year? university graduate, chief editor of a government ministry publishing house, with an annual cash income of 36,000 yuan. Wife, 58 years old, Party member, vice chief editor at a state-owned publishing house, with an annual cash income of 48,000 yuan. They have two sons. Both of them have a university degree and are economically independent.

The couple bought a 120-square-metre apartment for less than 100,000 yuan a few years ago. Recently, they bought a 120-square-metre new apartment at the system housing price without a mortgage. The market price of this apartment is 840,000 yuan. In compliance with regulations, they must sell their old apartment to the husband's work unit at a price of less than 100,000 yuan. The difference between the market price and the system price of his new apartment is 923,700 yuan, calculating in a mortgage. The annual "system housing income" for this family is 61,580 yuan and their annual household income is 145,580 yuan.

Both the husband and wife have company cars with drivers. The annual expenses on maintaining a car in Peking are approximately 24,000 yuan (including petrol, registration and maintaining fees). If we add car subsides into their income, their annual household income will be almost 200,000 yuan.

Case No. 4 (Interview No. 23, 2000)

Husband, 46 years old, four-year university graduate, an engineer in a state-owned computer factory, with an annual cash income of 36,000 yuan. Wife 44 years old, Party member and editor in a university publishing house, with an annual cash income of 30,000 yuan.

73 They have two apartments. One is on a university campus and the other is near the Zhongguancun area. The two apartments cost them a total of 50,000 yuan. On the housing market, the two apartments are valued at 400,000 yuan. The difference between the market price and the price they paid is 350,000 yuan. This will increase their annual household income by 23,300 yuan for the next 15 years. Currently they live in the apartment in the university and intend to rent out the other apartment. Annual rent will be 24,000 yuan. After renting the apartment their total annual household income will be about 113,300 yuan. 

Peking. Because the wife works at the university's publishing house, they do not pay "zanzhu fei (donations)" (1) to the school. Parents who do not work at the university have to pay 100,000 yuan for their child to study in the university's junior or senior high school. The wife said: "The proportion of students entering university from this school is very high. Even if parents are willing to make the 100,000 yuan donations, their children cannot be accepted by the school because there are no vacancies. I work in the university so we do not need to give 200,000 yuan in donations. In other words, I earn 200,000 yuan compared to other parents. In addition, we live on the university campus and don't need to pay for school accommodation for my son. Many parents have to spend 43,000 yuan a year for their children's accommodation in the school. I think of this also as family income for us."

this family's real income, including salary, "system housing income", rent and child education subsidies, their annual household income will be over 140,000 yuan. expenditure in Peking. Many parents want their children to study in good schools so that they can have a better chance of passing the university examination and have a better future. The educational quality of universities and some ministries' primary and junior high schools is generally better than others. If parents work in those universities and ministries, they can save a lot of money from not having to give donations to the schools. But other parents who do not work in the universities and ministries have to pay such "donations" in addition to tuition.

1. Zanzhu fei is a disguised form of school fees, which those parents whose children are not qualified to attend certain highly-regarded schools are "invited" to pay.

Case No. 5 (Interview No. 10, 2000)

Husband, 45 years old, four-year university graduate, Party member, and middle level manager in a state-owned company, with a cash income of 120,000 yuan in 1999. Wife, 43 years old, four-year university graduate, a journalist in a government ministry newspaper, with an annual cash income of 36,000 yuan in 1999. They have a daughter studying at senior high school.

They have two apartments. In 1997, they spent 20,000 yuan to buy their first apartment from the husband's work unit. In 1999, they spent 30,000 yuan to buy an apartment from the wife's work unit. On the housing market, the two apartments are valued at 400,000 yuan. As in case 4, this family's annual income will increase by 23,300 yuan over the next 15 years. They are planning to rent the recently bought apartment at an annual fee of 24,000 yuan. Now their annual cash income is about 159,300 yuan. Adding system housing income and rental income, they will have an annual income of 203,300 yuan $(156,000+23,300+24,000)$.

Case No. 6 (Interview No. 25, 2000)

Husband 45 years old, three-year? college graduate, Party member and vice division rank officer in a state-owned factory, with an annual cash income of 36,000 yuan. Wife, 45 years old, three-year college graduate, Party member and primary school teacher, with an annual cash income of 30,000 yuan. They have a son studying at a college.

In 1999 they bought a 90-square-metre apartment from the husband's work unit for 90,000 yuan. It is located on the northern third ring road. The market price for the 
same apartment in that area are 7,000 to 8,000 yuan per square metre. If we calculate their apartment at 7,000 yuan per square metre, the difference between the two housing system prices is 663,200 yuan. Dividing it by 15 (years) and add it into their household income, their annual household income will increase by 44,200 yuan for the next 15 years. The total annual income for this family is 110,200 yuan.

Case No. 7 (Interview No. 15, 2000)

81 Husband, 38 years old, four-year university graduate, senior editor in a financial newspaper with an annual cash income of 60,000 yuan. Wife, 42 years old, postgraduate, and senior manager in a private enterprise, with an annual income of 120,000 yuan. They have a three-year-old son.

The couple has two apartments. A few years ago, they bought an apartment for 20,000 yuan from the wife's former work unit, a large newspaper. The price of this apartment on the housing market is now 150,000 yuan. The second apartment is a 120-squaremetre apartment in Huilongguan residential area, outside the fourth ring road. The journey time from home to work in the city and home again is three hours on public transport. This residential area is the Peking municipal government's model housing area for economic and practical housing (jingji shiyong fang). The government makes no profits from building and selling these apartments. Even in such situations, the price per square metre was 2,600 yuan when they bought it in 1999 (in 2000 the price per square metre rose to 3,000 yuan). They paid $50 \%$ of the total price and borrowed $50 \%$ from a bank as a ten-year mortgage. The annual principal and interest are 20,000 yuan. After adding the "system housing income" and deducting mortgage payments, their household income is around 190,000 yuan.

83 The wife's wage can be regarded as high in Peking, but she feels she does not have job stability. She told us: "My income is good, but I have to work very hard and have always to be careful. My job is not very stable. From the day I started work in this company, I told myself I must keep this job for six months. I have worked in this company for almost three years but still I tell myself that this job could be only for the next six months."

Case No. 8 (Interview No. 7, 2000)

84 Husband, 36 years old, four-year university graduate, Party member, owner of a private enterprise. Before entering the business world, he was a vice-division level official in a bureau of the Peking municipal government. He left his work unit in 1993 to start his own business. From 1993 to 1996, his company did not make profits. In 1997, the company made some money. In 1998 and 1999, the company's net profit was around 300,000 yuan. Wife, 31 years old, from 1992 to the end of 1999 worked in a semi-stateowned enterprise (1). She first worked as software designer and in 1995 was appointed manager of one of the company's retail outlets in Zhongguancun. From 1995 to 1999, her average annual income was about 150,000 yuan. In late 1999, her retail outlet was pulled down because of developments in Zhongguancun area and she lost her job. From 2000 she started work in her husband's company. They do not have a child.

After they married in 1993 they lived in a 17-square-metre room in a courtyard building. In late 1997 they bought a 90-square-metre apartment in the Wangjing residential area outside the fourth ring road, at 4,500 yuan a square metre. At that time, housing buyers could not take out a mortgage and they paid 395,000 yuan in one lumpsum payment to buy the apartment. When we interviewed them, they were looking for a 200-square-metre residential and commercial apartment, priced about 9,000 yuan per 
square metre, near the eastern third ring road. They were planning to borrow $70 \%$ of the price with a mortgage and will use the new apartment for their business and also to live in. With the expansion of the husband's business, they need to have a betterlooking office, which must be near the business area so they can meet clients. After they buy the new apartment, in order to cut the company's expenses they will sell the present apartment and cancel a lease for renting the present office space.

1. The company she worked at was founded by two brothers as a private enterprise. Because its major business was in the telecommunication area, which is the state-monopolised sector, the company had to find a state-owned company as its sponsor. But it is a state-owned company in name only and actually privately-owned and run.

Case No. 9 (Interview No. 1, 2000)

Husband, 33 years old, four-year university graduate, marketing manager in a small foreign-owned company, with an annual cash income of 100,000 yuan. Wife, 33 years old, Party member, four-year university graduate, manager for a small foreign-owned company (1), with an annual cash income of 60,000 yuan. They do not have a child.

The husband and wife used to work in two different state-owned enterprises. Because the husband's enterprise lost money and he was very badly paid, he decided to "retire" at the age of 25 . He was allowed to do this according to the factory's own policy, which was called "neibu tuixiu" (The employees in the factory could retire before the legal retirement age because the factory wanted to reduce a number of workers and staff). As a "nei tui" employee, he would receive a small amount of money every month and could enjoy some of the benefits for employees of state-owned enterprises, including living in company housing. In 1999, the enterprise sold him a new 65-square-metre apartment priced at 90,000 yuan. The apartment building is located within the northern section of the third ring road. The market price of that apartment is 6,500 yuan per square metre. His home is valued at 422,500 yuan on the market. The difference in the two system housing prices is 425,700 yuan after paying off the mortgage. This will increase their household income by 29,000 yuan per year for the next 15 years.

After he bought the apartment, the factory was also sold to a private real estate developer. Now he has become a true employee "outside the system" and is no longer entitled to benefits from the system. The husband told us: "Although our income is not low, our jobs are not stable because the companies are very small. My company has less than twenty employees and my wife's company has only eight employees. At the moment we are young and do not have a child. But we must save money for many expected and unexpected things, such as raising and educating a child, sickness, and even accidents. We are no longer employees "within the system" and nobody will take care of us except ourselves."

1. The owners of both the husband and wife's companies are overseas Chinese. They left China in the 1980s but returned to start their business in the mid-1990s.

Case No. 10 (Interview No. 38, 2000)

89 A single female clerk, 28 years old, four-year university graduate, working at a foreign media company and also working for a foreign marketing research company on a project-by-project basis.

Her annual income was US $\$ 18,000$ in 1999 . Because the company does not give her health insurance and a pension plan, she has to buy them herself. Now she lives with her parents and has not yet considered buying her own apartment. When we asked why 
she was not going to buy an apartment, she told us: "It looks like my income is not bad. Among my university classmates, my income belongs to the group of the highest income earners. But I don't have any feeling of job security. Except for the salary, the company doesn't pay anything for me. If one day I lost this job, I don't know what sort of job I could find and when, so I must save money. Buying an apartment by myself is totally beyond my plans at least for the next few years".

\section{NOTES}

1. See Li Peilin (ed.), Zhongguo xinshiqi jieji jieceng baogao (Class and Status in a New Period in China), Shenyang: Liaoning renmin chubanshe, 1995. Ren Caifang and Cheng Xuebin, "Chengshi jumin shouru bu pingdeng yianjiu" ("Studying Disparity of Urban Residents' Income"), Jingji yanjiu cankao (Reference of Economic Research) No. 157, 1996. David S. G. Goodman, "The People's Republic of China: The party-state, capitalist revolution and new entrepreneurs," in Richard Robison, David S. Goodman (ed.), New Rich in Asia: Mobile Phones, McDonalds and Middle-Class Revolution, London and New York: Routledge 1996. Yang Yiyong, Gongping yu xiaolv: Dangdai Zhongguo shouru feipei wenti (Equality and Efficiency: Issues on Income and Distribution in China), Peking: Jinri Zhongguo chubanshe, 1997. He Qinglian, Xiandaihua de xianjing: Dangdai Zhongguo de jingji shehui wenti (The Trap of Modernization: Social and Economic Problems of Contemporary China), Peking: Jinri Zhongguo chubanshe, 1998. Zhao Renwei, Li Shi, Carl Riskin (ed.), Zhongguo jumin shouru fenpei zai yanjiu (Restudy of the Income Distribution of China Residents), Peking: Zhongguo caizhen jingji chubanshe, 1999. Fan Xinmin, Dushi Liehen (Urban Cracks), Jingji ribao chubanshe, 2000. Li Qiang, Shehui fenceng yu pinfu chabie (Social Stratification and Disparity between the Rich and Poor), Xiamen: Lujiang chubanshe, 2000.

2. David S. G. Goodman, "The New Middle Class", in Merle Goldman, Roderick MacFarquhar (ed.), The Paradox of China's Post-Mao Reforms, Cambridge, Mass: Harvard University Press, 1999, pp. 241-261.

3. According to The Provisional Regulations of Private Enterprises of the People's Republic of China, promulgated in June 1988, a private enterprise refers to an economic organ that makes profit and employs more than eight workers. An individual entrepreneur refers to a person who hires less than eight workers.

4. Zhao Renwei, Li Shi, "Zhongguo jumin shouru chaju de kuoda jiqi yuanyin" ("The Increase in the Widening Income Gap of Chinese Citizens and Reasons") and John Knight, Li Shi, Zhao Renwei, "Zhongguo chengzheng gongzi he shouru chayi de quyu fenxi" ("A Regional Analysis of Differences in Urban Incomes in China"), in Zhao Renwei, Li Shi, Carl Riskin (ed.), Zhongguo jumin shouru fenpei zai yanjiu (Further Analysis on the Income Distribution on China Residents), Peking: Zhongguo caizhen jingji chubanshe, 1999, pp. 47-67, pp. 253-289.

5. Erik Olin Wright, Classes, London: Verson, 1985, p. 80.

6. Erik Olin Wright, Class Counts: Comparative Studies in Class Analysis, Cambridge University Press 1997, p. 17. 
7. Val. Burris, “The Neo-Marxist Synthesis of Marx and Weber on Class," in N. Wiley (ed.) The Marx-Weber Debate, Newbury Park, CA: Sage Publications, 1987. Frank Parkin, Marxism and Class Theory: A Bourgeois Critique, New York: Columbia University Press, 1979. Erik Olin Wright, Class Structure and Income Determination, New York: Academic Press, 1979. Anthony Giddens, The Class Structure of Advanced Society, New York: Harper and Row, 1973.

8. Max Weber, Economy and Society: An Outline of Interpretive Sociology, 2 vols., G. Roth and C. Wittich (ed.), Berkeley, University of California Press, 1978, p. 302.

9. Karl Marx and Frederick Engels, Manifesto of the Communist Party, In Karl Marx and Frederick Engels, Selected Works, Vol. 1, New York: International, 1972, pp. 35-63. Karl Marx, Capital, Vol. 3, New York: International, 1973, pp. 290-301.

10. Max Weber, The Theory of Social and Economic Organization, Talcott Parsons (ed.), New York: Free Press, 1964, pp. 424-29. Max Weber, Economy and Society: An Outline of Interpretive Sociology, Vol. 2, G. Roth and C. Wittich (ed.), Berkeley, University of California Press, 1978, p. 302.

11. C. Wright Mills, White Collar, New York, Oxford University Press, 1956.

12. In recent years, there have been many studies on the income of China's new rich and the disparity of the urban rich and the urban poor. See Li Peilin (ed.), Zhongguo xinshiqi jieji jieceng baogao (Class and Status in a New Period in China), Shenyang: Liaoning renmin chubanshe, 1995. Ren Caifang and Cheng Xuebin, "Chengshi jumin shouru bu pingdeng yianjiu" ("Studying Disparity of Urban Residents' Income”), Jingji yanjiu cankao (Reference of Economic Research) No. 157, 1996. Yang Yiyong, Gongping yu xiaolv: Dangdai Zhongguo shouru feipei wenti (Equality and Efficiency: Issues on Income and Distribution in China), Peking: Jinri Zhongguo chubanshe, 1997. Zhu Qinfang, "Chengzheng pinkun renkou de tedian, pinkun yuanyin he jiekun duice" ("Causes and Characteristics of the Urban Poor and Countermeasures"), Shehui kexue yanjiu (Research in Social Sciences), No. 1, 1998. Zhao Renwei, Li Shi, Carl Riskin (ed.), Zhongguo jumin shouru fenpei zai yanjiu (New Study on the Income Distribution of China Residents), Peking: Zhongguo caizhen jingji chubanshe, 1999. Li Qiang, Shehui fenceng yu pinfu chabie (Social Stratification and Disparity between the Rich and Poor), Xiamen: Lujiang chubanshe, 2000.

13. Li Peilin (ed.), Zhongguo xinshiqi jieji jieceng baogao (Class and Status in a New Period in China), Shenyang: Liaoning renmin chubanshe, 1995, pp. 37-40.

14. Li Qiang, "Shichang zhuanxing yu Zhongguo zhongjian jieceng de daiji gengti"("Market Transition and Replacement of Social Intermediate Stratum"), Zhanlv yu guanli (Strategy and Management), No. 34, 1999, pp. 35-44.

15. Li Qiang, Shehui fenceng yu pinfu chabie (Social Stratification and Disparity between the Rich and Poor), Xiamen: Lujiang chubanshe, 2000, pp. 82-104.

16. Yin Yiping, Gaoji hui (Elegant Grey), Peking: Zhongguo qingnian chubanshe, 1999, pp. 278-80. Shi Tao, "Shuishi zhongchan jieji" ("Who is the Middle Class"), Shishang zazhi (Vogue Magazine), see http: 77fashion.sohu.com7frends799217frends9910-46.html 17. Yin Yiping, Gaoji hui (Elegant Grey), Peking: Zhongguo qingnian chubanshe, 1999, p. 280.

18. David S. G. Goodman, "The New Middle Class", in Merle Goldman, Roderick MacFarquhar (ed.), The Paradox of China's Post-Mao Reforms, Cambridge, Mass: Harvard University Press, 1999, pp. 248-261.

19. It goes: "Yi lei ren shi gongpu, gao gao zai shang xiang qingfu; er lei ren zuo guandao, touji daoba you ren bao; san lei ren gao chengbao, chi he piao du quan 
baoxiao; si lei ren lai zulin, zuo zai jiali na lirun; wu lei ren da gai mao, chi le yuangao chi beigao. Liu lei ren shoushu dao, yao li chuaiman hong zhibao; qi lei ren dang yanyuan, niu niu pigu jiu zhuanqian; ba lei ren gao xuanchuan, ge san cha wu jie ge chan: jiu lei ren wei jiaoyuan, shan zhen hai wei ren bu quan; shi lei ren zhuren wong, lao lao shi shi xue Lei Feng."(The first group is public servants. They are prominent persons who live comfortably. The second group is bureaucratic profiteers, who can make money illicitly under the protection of powerful officials in the government. The third group is contractors of state and collective enterprises. The enterprises pay for these contractors who frequent brothels, gambling casinos and bars. The fourth group of people make money by renting their housing to the people who do business. The fifth group is the people who wear "big lip caps" - policemen, judges and public procurators. They may receive bribes from both the defendants and prosecutors. The sixth group is surgeons who may get money from patients as gifts. The seventh group is performers who can make money by singing and dancing. The eighth group is the people who work in the Party propaganda department. Their craving for good food is occasionally satisfied. The ninth group is teachers. They have no opportunity to taste such delicacies. The tenth group is ordinary people. All they can do is learn from the model soldier Lei Feng.) This reflects the resentment of many people of the existing social inequality and corruption.

20. See Case No. 2, Interview No. 14, 2000.

21. Interview No. 9, 2000.

22. Interview No. 5, 2000.

23. See Case No. 7, Interview No. 15, 2000.

24. Interview No. 46, 2000.

25. Interview No. 3, 2000.

26. Azizur Rahman Khan and Carl Riskin, "Income and Inequality in China: Composition, Distribution and Growth of Household Income 1988 to 1995", China Quarterly, No. 154, June 1998, p. 231.

27. Li Shi, Wei Zhong, B. Gustaffsson, "Zhongguo chengzheng jumin de caichan fenpei" ("Distribution of Assets of China's Urban Residents"), Jingji yanjiu (Research of Economy) No. 3, 2000, pp. 16-23.

28. See Guowuyuan guanyu jin yi bu shenhua chengzheng zhufang zhidu gaige jiakuai zhufang jianshe de tongzhi (The Circular of the State Council on Deepening the Reform of Urban Housing System and Speeding Up Construction of Residential Housing), State Council Document No. 23, 1998, issued on July 3rd 1998 and Zaijing zhongyang he guojia jiguan jin yi bu shenhua zhufang zhidu gaige shishi fangan (Plane for Implementing Housing Reform of Central Party Organs and Central Government Organs in Peking), endorsed by the general office of the Central Party Committee and the General Office of the State Council on August 16th 1999.

29. In China not only Party and government organisations and the people who work in these organisations have administrative rank, but also other state-owned work units and their employees enjoy corresponding rank. For example, most universities and some hospitals are ranked at the bureau level. Although people work in these universities and hospitals as professors and doctors, they can have the same size living space and other fringe benefits like corresponding rank officials in the Party and government organisations.

30. Interview No. 43, 2000.

31. Liu Guoning, Jingpin gouwu zhinan (Shopping Guide), see 
http//www.sinoi.com/realestate/bin/RS_Mar_H/RS_ar_H.asp?path=/realestate/RS_Mar_H/ 3808.htm

32. Xie Haoran, Zhongguo jianzhubao (China Construction Daily,) see http/www.sinoi.com/realestate/binIRS_Media/RS_Media.asp?=/realestate/RS_Media/3734.htm 33. Statistics of the People's Bank of China show that housing and consumption loans from financial organisations increased 194.9 billion yuan from January to October 2000, 124.6 billion yuan more compared to the same period in 1999 . It accounted for $41 \%$ of the total loans of these financial organisations. Forty percent of this 194.9 billion yuan was housing loans.

According to a report in Beijing Chenbao (Peking Morning Post), 80\% of individual consumption loans are borrowed for house-buying. (Fan Ji, Peking Morning Post, see

http/www.sinoi.com/realestate/binIRS_Media/RS_Media.asp?=/realestate/RS_Media/3690.htm) In 2000 the Centre of Economic Monitoring of the China Statistical Bureau and MasterCard International conducted an investigation on loans to 2,100 citizens in seven big cities, including Peking, Shanghai and Guangzhou last year. The investigation shows that loans for housing, education, car, and medical service respectively account for $74.8 \%, 10 \%, 9.2 \%$ and $2.5 \%$. (November 14th 2000, Xinhua News Agency)

34. Beijing Statistical Yearbook 1999, China Statistical Publishing Housing, 1999, p. 102.

35. See Case No. 3, Interview No. 17, 2000

36. Interview No. 55, 2000.

37. Xu Xinxin, "Maixiang 21 shiji de Zhongguo zhiye shengwang yu shimin zeye quxiang" ("Target Occupations and Employment in China in the $21^{\text {st }}$ Century"), in Ru Xin, Lu Xueyi, and Lu Jianhua (eds) 2000 nian: Zhongguo shehui xingshi fenxi yu yuce (2000: Analysis of China's Social Situation and Prediction), Shehui kexue wenxian chubanshe, 2000, pp. 19-39.

38. Victor Nee, "A Theory of Market Transition: From Redistribution to Markets in State Socialism.” American Sociological Review, 1989, 54, pp. 663-681. “Organizational Dynamics of Market Transition: Hybrid Forms, Property Rights, and Mixed Economy in China." Administrative Science Quarterly, 1992, 37, pp. 1-27. “The Emergence of a Market Society”, American Journal of Sociology, 1996, 101, pp. 908-949.

39. Yasheng Huang, "Economic Bureaucracies and Enterprises During Reforms." China Quarterly, No. 123, 1990, September, pp. 431-458.

40. John R. Logan and Yanjie Bian, "Inequalities in Access to Community Resources in China City." Social Forces, 1993, 72(2), pp. 555-576. Yanjie Bian, Work and Inequality in Urban China, Albany: State University of New York Press, 1994. Yanjie Bian and John R. Logan, "Market Transition and the Persistence of Power: The Changing Stratification System in Urban China", American Sociological Review, 1996, 61, pp. 739-758.

41. Douglas Guthrie, Dragon in a Three-Piece Suit: Foreign Investment, Regional Bureaucracies, and Market Reform in China, Princeton: Princeton University Press, 1999. 